which he has been required to pay in taxes. Finally, where there is a power to consume only for purposes of maintenance and support, the life tenant should pay the tax in a fiduciary capacity. When the individual is in a position where he must rely on consumption of corpus for his maintenance and support, taxing him as owner of capital gains would tend to increase his needs. In order to satisfy them he would be forced to consume corpus assets in such amount as to offset the cost incurred by the tax assessment. This method could produce additional hardships resulting from delays between time of payment of the tax and acquisition of liquidated corpus assets. Where the life tenant does not rely on corpus for maintenance and support, taxing him as owner would be unjust, since his position would not enable him to acquire, absolutely, the gain for which he would be taxed.

\title{
ASSERTION OF THE ATTORNEY-CLIENT PRIVILEGE TO PROTECT THE CLIENT'S IDENTITY
}

The attorney-client privilege, which prevents disclosure of statements made confidentially to an attorney, 1 has been limited by the rule that the client's identity falls outside the scope of the privilege. ${ }^{2}$ This judicially imposed limitation has recently been subjected to close scrutiny. In three recent cases the privilege has been invoked to protect the identity of clients. ${ }^{3}$ These cases reflect an emphasis on the underlying purpose of the attoney-client privilege and a tendency to reject the rule, that the client's identity is not privileged, when it conflicts with that purpose. It is the effect of these cases on the general rule which constitutes the principal topic of this note.

The attorney-client privilege, stated generally, provides that confidential statements, communicated in the course of a professonal relationship between an attorney and his client, may not be divulged by the attorney without the client's consent. ${ }^{4}$ The attorney-client privilege formerly was considered a matter of the attorney's honor; but it is now considered to be the privilege of the client. 5 Modern justifications for the attorney-client privilege are based on social policy. The most frequently stated justification is that the privilege

18 WiGMORE, EVIDENCE $\$ 2290$ (3d ed. 1940).

2 E.g., United States v. Pape, 144 F.2d 778 (2d Cir. 1944); Goddard v. United States 131 F.2d 220 (5th Cir. 1942); People ex rel. Vogelstein v. Warden, 150 Misc. 714, 270 N.Y. Supp. 362 (Sup. Ct. 1934), aff'd. mem., 242 App. Div. 611, 271 N.Y. Supp. 1059 (1934); Annot., 114 A.L.R. 1321 (1938).

3 Baird v. Koerner, 279 F.2d 623 (9th Cir. 1960), 13 AlA. L. Rev. 196 (1960), 47 VA. L. REv. 126 (1961). Ex parte Enzor, 270 Ala. 254, 117 So. 2d 361 (1960); In re Kaplan 8 N.Y.2d 214, 168 N.E.2d 660, 203 N.Y.S.2d 836 (1960).

497 C.J.S. Witnesses $\$ 276$ (1957). For a more detailed statement of the general rule see 8 WIGMORE, EvidENCE $\$ 2292$ (3d ed. 1940). The attorney-client privilege has been codified in many jurisdictions in essentially its common law form. Id. at 558 .

58 WIGMORE, EVIDENCE $\$ 2290$ (3d. ed. 1940). 
promotes freedom of consultation by removing the client's apprehension that confidential disclosures can be elicited from his attorney. 6 An additional and more cynical rationale is that without the privilege a disreputable lawyer would have an advantage; he would be the only one to whom clients would confidently make full disclosure since, for a large enough retainer, he would assure his client that he would not testify concerning any communications made to him. Another factor may be the general unwillingness of the law to allow a lawyer to be a witness. No matter what rationale has been offered, the attorney-client privilege has been, almost from its inception, regarded by both courts 7 and commentators ${ }^{8}$ with skepticism. The harm done by the attorney-client privilege in the suppression of truth in litigation or official investigations is apparent to the courts, and they have accordingly tended to construe the privilege strictly. ${ }^{9}$ It is not surprising, therefore, that courts have created various limitations at the periphery of the privilege.

I

One limitation is the rule that "the client's identity does not come within the scope of the privilege." 10 The courts have generally declared that the subject matter of the employment, not the fact of the employment, is within the privilege. 11 The courts have not, however, always applied their formal declarations, and in many instances they have protected the client's identity.

Several situations can be presented where revealing the client's identity

68 Wigmore, Evidence $\$ 2291$ (3d. ed. 1940). See Model Code of Evidence rule 210, comment (1942).

7 E.g., Alden v. Goddard, 73 Me. 345, 348 (1882). " 'I think this confidence in the case of attorneys is a great anomaly in the law.' It requires limitation rather than extension."

8 E.g., Morgan, Foreword to Model Code of Eymence at 27 (1942).

${ }^{9}$ See, e.g., Satterlee v. Bliss, 36 Cal. 489 (1869). More modern cases also tend towards strictly construing the communications that are to be privileged. Prichard v. United States, 181 F.2d 326 (6th Cir. 1950), aff'd per curiam 339 U.S. 974 (1950); United States v. United Shoe Mach. Corp., 89 F. Supp. 357 (D. Mass. 1950). For a summary of recent developments in the field of privileged communications, see Note, 5 VAND. L. Rev. 590 (1952).

10 People ex rel Vogelstein v. Warden, 150 Misc. 714, 719, 270 N.Y. Supp. 362, 369 (Sup. Ct. 1934). Most of the earlier cases also use similar broad phrasing of the general rule. See, e.g., Mobile \& Montgomery Ry. v. Yeates, 67 Ala. 164 (1880); Satterlee v. Bliss, 36 Cal. 489 (1869); Martin v. Anderson, $21 \mathrm{Ga} .301$ (1857). More modern authorities, in most instances, do not state the rule with as much generality. E.g., 58 AM. JUR. Witnesses $\S 507$ (1948), where it is stated that the attorney-client privilege "does not ordinarily apply to ... the ... name of the person employing" the attorney.

11 E.g., United States v. Pape, 144 F.2d 778 (2d Cir. 1944); Goddard v. United States, 131 F.2d 220 (5th Cir. 1942); Gretsky v. Miller, 160 F. Supp. 914 (D. Mass. 1958). The court in the Gretsky case stated that "it is elementary that the privilege attaches not to the relationship but only to certain communications made by the client to the attorney.... The fact of representation is not within the privilege. ... Indeed it is a necessary preliminary act, to be established before any privilege can be asserted." Id. at 915 . The assumption necessary for this argument, that the identity of the client is never a confidential communication, is factually incorrect. 
would reveal so much of the confidential relationship between an attorney and his client that a literal application of the general rule would reach an unsound result: (1) A client employs an attorney to pass information to an investigating committee without revealing his name, because he fears outside reprisals.12 (2) An attorney posts bond on behalf of his client for a third person. (3) An attorney attending an inquest into a hit and run automobile accident is required to take the stand and reveal on whose behalf he is attending the inquest. 13 The general rule excluding the client's identity from the privilege cannot adequately deal with such situations; they must be considered on their separate facts. ${ }^{14}$

When the cases in which the general rule has been applied are analyzed, the broad scope of the rule15 may be understood. The vast majority of the cases where the general rule has been applied fall into three categories: (1) decisions based upon the rule, applicable in all the attorney-client privilege cases, that a communication to an attorney in furtherance of a future crime is not privileged;16 (2) decisions based upon the general proposition that the parties to litigation are entitled to know who their opponents are;17 and (3) decisions where the confidence necessary for sustaining the privilege was not present.18

Where the identity of the client is communicated in furtherance of a future crime or anti-social conduct, the courts have had little trouble in denying the

${ }_{12}$ See In re Kaplan, 8 N.Y.2d 214, 168 N.E.2d 660, 203 N.Y.S. $2 d 836$ (1960). (dicta).

13 United States v. Mammoth Oil Co., 56 Ont. L.R. 635, 643, 2 D.L.R. 966,976 (1925)

14 See 8 Wigmore, Evidence $\$ 2313$ (3d ed. 1940), where Professor Wigmore, in regard to cases concerning the client's identity, states that "no doubt much ought to depend upon the circumstances of each case."

15 In Mauch v. Commissioner, 113 F.2d 555 (3d Cir. 1940), the court, in referring to the authorities which exclude bare identity from the privilege states that: "Their reasoning is rather too general and not impressive, based as it is on some idea that the privilege does not attach to the creation of the relation...." Id. at 556. See Judge Barnes' breakdown of the majority cases in the Baird opinion. Baird v. Koerner, 279 F.2d 623, 632 (9th Cir. 1960).

16 Where the party is being tried for a crime in furtherance of which the communication to the attorney was made and evidence has been introduced giving "color" to the charge, it is well settled that the communication is no longer privileged. E.g., Pollock v. United States, 202 F.2d 281 (5th Cir. 1953); In re Selser, 15 N.J. 393, 105 A.2d 395 (1954), 33 CHI. KeNT L. Rev. 271 (1955); 24 FordhaM L. Rev. 290 (1955); 29 Tul. L. Rev. 785 (1957). In re Stein, 1 N.J. 228, 62 A.2d 801 (1949); Matthews v. Hoagland, 48 N.J. Eq. 455, 21 Atl. 1054 (1891); Williams v. Williams, 108 S.W.2d 297 (Tex. Civ. App. 1937); 58 AM. Jur. Witnesses § 516 (1948); 8 WIGMORE, EVIDENCE $\$ 2298$ (3d ed. 1940).

17 See 8 WIGMORE, EVIDENCE $\$ 2313$ (3d ed. 1940).

18 See, e.g., Wilcoxon v. United States, 231 F.2d 384 (10th Cir. 1956), cert, denied, 351 U.S. 943 (1956). On cross examination the defendant was compelled to disclose certain questions he had requested his attorney to ask a government witness at a preliminary hearing. United States v. Shibley, 112 F. Supp. 734 (S.D. Cal. 1953); Spencer v. Burns, 413 Ill. 240, 108 N.E.2d 413 (1952); Baum v. Denn, 187 Ore. 401, 211 P.2d 478 (1949). 
claim of privilege to protect the client's identity19 since the entire interview would be considered outside the privilege. 20 Application of the attorney-client privilege to prevent the revelation of a communication in furtherance of a crime would place the courts in the ludicrous position of holding out their officers as silent accomplices to crime. The problem in cases of this type is to distinguish between communications made to an attorney as to past transactions, and those made in regard to future transactions since communications concerning past fraudulent transactions are normally privileged.21

The second category of cases requiring disclosure is based upon the oftenstated principle that "every litigant is in justice entitled to know the name of his opponents. He cannot be obliged to struggle in the dark against unknown forces." 22 This principle was the original justification for the rule excluding the client's identity from the attorney-client privilege. The rule, therefore, is rooted in civil litigation - particularly in ejectment suits ${ }^{23}$ where the parties to the litigation might be ignorant of the identity of their opponents. In civil litigation generally, where the client is either the plaintiff 24 or the defendant, 25 the principle of identifying parties to litigation should be applicable. It is certainly within the court's power to require the parties directly involved in its proceedings to be identified. The fundamental premise of our adversary procedure is that the parties to litigation are vitally interested therein and that the judgment can affect their interest. If attorneys were allowed to appear in court and represent unidentified litigants, there would not be the necessary clash of adverse interests. Judicial machinery may be abused by parties to litigation remaining unidentified. The courts on their own volition, to prevent this abuse, may require an attorney to reveal the name of the

19 See Application of Franklin Washington Trust Co., 1 Misc. 2d 1001, 148 N.Y.S.2d 731 (Sup. Ct. 1956). In this case a building was conveyed to the attorney's clerk to avoid confiscation in satisfaction of a judgment. The attorney would not reveal who the client was on the basis of the attorney-client privilege, but the court held that the communication was not within the attorney-client privilege, since the attorney's services had been used to perpetrate a fraud. Cf., In re Sawyer's Petition, 229 F.2d 805 (7th Cir. 1956) (dictum), 45 CALIF. L. Rev. 75 (1957); In re Selser, 15 N.J. 393, 105 A.2d 395 (1954).

20 See generally Pollock v. United States, 202 F.2d 281 (5th Cir. 1953); Williams v. Williams, 108 S.W.2d 297 (Tex. Civ. App. 1937).

21 Williams v. Williams, supra note 20.

228 WIGMORE, EVIDENCE $\$ 2313$, at 608 (3d ed. 1940).

23 Stephens v. Mattox, 37 Ga. 289 (1867); Martin v. Anderson, 21 Ga. 301 (1857). (An attorney in an ejectment action was compelled to testify whether a certain party had given him instructions to sue.)

24 Brown v. Payson, 6 N.H. 443 (1833).

25 See Dunipace v. Martin, 73 Ariz. 415, 242 P.2d 543 (1952). The plaintiff had reason to believe that the attorneys opposing him represented an insurance company in addition to the one he had sued. The court declared that he could properly ask the name of the unknown insurance company, but held that under the particular circumstances of the case there was no reversible error. 
person who has authorized him to appear. ${ }^{26}$ Basing the decisions which require attorneys in civil litigation to disclose the identity of their clients on the general rule that the identity of the client is not privileged is both misleading and unnecessary; notwithstanding the attorney-client privilege, the efficient administration of justice requires that parties to civil litigation be identified.

The requirement that parties to litigation be identified, although formerly applied only in civil litigation, has been extended to cover criminal proceedings. The most far-reaching decision is United States v. Pape.27 Pape was accused of violating the White Slave Traffic Act, 28 and the district court required Pape's attorney to reveal that he had defended the allegedly transported woman in an earlier prostitution charge. The Court of Appeals for the Second Circuit disregarded the incriminating nature of this testimony, and held that under the circumstances of the case the identity of the client was not privileged. Judge Learned Hand, although agreeing that the defendant's hiring the attorney for himself was not a privileged communication, dissented on the ground that the defendant's instruction to his attorney to appear for the woman "was a communication between an attorney and client, a step in his own defense... [and] that direction to his own attorney ... was as much a privileged communication as any direction would have been." 29 It is difficult to see how hiring an attorney to defend someone else can adversely affect the administration of justice, yet it seems probable that the Pape decision may have the effect of discouraging this practice. The evidence offered in Pape was an important step in connecting the defendant with the woman's prostitution, and it is just this type of incriminating evidence which attorneys are not normally forced to disclose. Whether the interests of the government in prosecuting an alleged violator of the White Slave Traffic Act were sufficient to require the defendant's attorney to disclose this evidence remains a troublesome question.

The court in Pape relied on United States v. Lee 30 and Vogelstein v. War$d^{2} n^{31}$ to support its conclusion. In Lee the defendant had fled from justice,

${ }^{26}$ See Alger v. Turner, 105 Ga. 178, 31 S.E. 423 (1898); Ninety-nine Plaintiffs v. Vanderbilt, 1 Abb. Pr. 193 (N.Y. Sup. Ct. 1855). KaN. Rev. STAT. \& 7-107 (1949), provides that the court may require the attorney to prove "the authority under which he appears." For an application of the statute, see Klingberg v. Atchison T. \& S.F. Ry., 137 Kan. 523, 21 P.2d 405 (1933).

27144 F.2d 778 (2d Cir. 1944).

29144 F.2d. at 783.

2818 U.S.C. $\$ 398$ (1958).

30107 Fed. 702 (C.C.E.D.N.Y. 1901).

31150 Misc. 714, 270 N.Y.Supp. 362 (Sup. Ct. 1934). Contra, Ex parte McDonough, 170 Cal. 230, 149 Pac. 566 (1915). The Vogelstein case was recently followed in In re Richardson, 31 N.J. 391, 157 A.2d 695 (1960). (Purpose of the questioning was to acquire evidence against a present defendant by requiring an attorney to reveal the identity of a third party client). But see, Ex parte Schneider, 294 S.W. 736 (Mo. Ct. App. 1927). 
and the attorney who had previously represented the defendant was called before a grand jury investigating the disappearance and required to reveal the name of the party who had retained him to defend the fugitive. The court acknowledged that the attorney-general's purpose was to obtain the client's name in order to show the client's possible complicity in the disappearance; nevertheless, it declared that "the court has a right to know that the client whose secret is treasured is actual flesh and blood, and demand his identification...."32

In Vogelstein a grand jury was conducting an inquiry into the policy game. An attorney who was called as a witness was required to disclose the name of a client who had previously hired him to represent certain defendants in a policy-game prosecution. The New York Court of Appeals followed the Lee case, which it considered directly in point, and held that the identity of the client was not privileged.

In both Lee and Vogelstein the prejudice to the individual client's interest caused by compelled disclosure of his identity was not sufficient to weight the balance in favor of privileging his identity. An important factor weighing against the privilege is the widespread possibility for sharp practices which would attend the privilege to cloak a client's identity in secrecy. Justice Shientag, defending the court's conclusion in Vogelstein, stated that "the conclusion reached would seem to be inevitable, if we are to maintain the honor of the profession, and make an officer of the court an agency to advance the ends of justice, rather than to be used as an instrument to subvert them." 33 An additional factor in these cases may be the general tendency of the courts to limit the application of customary exclusionary rules of evidence in grand jury proceedings. ${ }^{34}$ In order to facilitate the investigatory powers of the grand jury the fullest possible disclosure may be necessary. Nevertheless, it may be socially undesirable for grand juries in the guise of obtaining a client's identity to obtain incriminating evidence concerning the client from his attorney.

The Lee and Vogelstein cases also help determine how far back in the criminal process the principle of identifying parties to litigation can be extended. These cases at the very least have included grand jury proceedings within the scope of "litigation." The extent to which the principle may be extended is as yet unsettled.

The third category of decisions requiring disclosure includes those cases where the court has determined that the identity of the client was not a confidential communication within the technical meaning of that term. ${ }^{35}$ Because

32107 Fed. at 704.

33150 Misc. 714, 721, 270 N.Y.Supp. 362, 371.

34 See generally, Comment, Rules of Evidence in Disbarment, Habeas Corpus, and Grand Jury Proceedings, 58 MrCH. L. REv. 1218 (1960).

35 Where a third person is present the communication is generally not considered confidential. In re Quick's Estate, 161 Wash. 537, 297 Pac. 198 (1931). Nor is the communi- 
the courts have used this category as a "catch all," three distinct factual variations are contained within it: (1) cases where the attorney is the defendant; 36 (2) cases where a past client is the present defendant and the attorney seeks to conceal his earlier representation;37 and (3) cases where the client has denied the fact of representation. ${ }^{38}$

Mauch v. Commissioner ${ }^{39}$ vividly illustrates the factors at work in the first situation. In Mauch the attorney was the defendant in an income tax fraud trial. He asserted that certain funds which he had not declared as income were not his funds, but the funds of certain clients whom he refused to identify. The court had little trouble in deciding that the names of the clients had to be revealed. It is now well established that the attorney-client privilege is designed to protect the client, and to allow the attorney to assert the privilege to protect his own interest fails to achieve this purpose. Neither the administration of justice nor the promotion of open consultation could in any way be served by applying the privilege to conceal an attorney's fraud.40

In the second situation, for purposes of identification an attorney is asked whether or not the defendant is the person he represented in an earlier proceeding. ${ }^{41}$ Technically, in these cases it is the fact of representation which is at issue rather than the identity of the client. The fact of the attorney's representation at the earlier proceeding could be easily determined from the record of that proceeding; therefore, a claim that the fact of representation was a confidential communication seems particularly inappropriate. Little but delay would attend privileging the fact of representation.

The third factual variation can be illustrated by Behrens v. Hironimus.42

cation considered confidential where the matter is to be related to the public or revealed to a third party. Himmelfarb v. United States, 175 F.2d 924 (9th Cir. 1949). See generally 8 Wigmore, EvidenCE § 2311 (3d ed. 1940); MCCORMICK, EVIDENCE \$ 95 (1954).

36 See, e.g., Mauch v. Commissioner, 113 F.2d 555 (3d Cir. 1940); State v. Toscano, 13 N.J. 418, 100 A.2d 170 (1953); cf., In re Illidge, 162 Ore. 393, 91 P.2d 1100 (1939) (residence of client not privileged).

37 See, e.g., Rand v. Ladd, 238 Iowa 380, 26 N.W.2d 107 (1947); State v. Fisher, 126 W.Va. 117, 27 S.E.2d 581 (1943); State v. Powell, 161 Wash. 514, 297 Pac. 160 (1931).

${ }^{38}$ See, e.g., Behrens v. Hironimus, 170 F.2d 627 (4th Cir. 1948); Tomlinson v. United States, 93 F.2d 652 (D.C. Cir. 1937); Kaufman v. United States, 212 Fed. 613 (2d Cir. 1914).

39113 F.2d 555 (3d Cir. 1940).

40 An additional justification for the Mauch case may be premised on an implied waiver theory. The court stated that "The record discloses no offer by the petitioner [the attorney] to obtain the permissible waiver from his anonymous clients. The absence of such offer may very well dispense with any necessity for a present determination of where the scale should come down. If we assume, however, a refusal to waive. ..." Id. at 556. The fact that the revelation of the client's identity would probably not tend to harm the client is an additional circumstance which would lend credence to an implied waiver theory.

41 Cases cited note 37 supra.

42170 F.2d 627 (4th Cir. 1948). 
In Behrens the privilege was asserted so that a client's testimony, that she had not had an attorney during the course of her trial, could not be controverted. An attorney's testimony that she had represented the defendant was admitted by the court, and the attorney-client privilege was held inapplicable. The client by denying the fact of representation opened the door to the admission of any evidence that might prove the fact of representation at the earlier trial. "He cannot blow hot and cold at the same time."43 Sustaining the privilege under these circumstances to prevent normal cross examination would encourage deception and defeat the purpose of cross examination.

\section{II}

Where the courts have determined that the client had reason to believe that his name would be confidential, the courts have been reluctant to exclude the client's identity from the privilege. 44 When the facts have warranted the application of the privilege, courts have disregarded the overgenerality of the majority rule. Where the revelation of the cleint's identity would have the collateral effect of revealing the previous connections, conduct, or transactions of the client, the privilege has been generally sustained. 45

The unifying factor in cases which have permitted nondisclosure of the client's identity appears to be judicial concern that the client would be prejudiced in some substantial way if his identity were revealed. Three recent cases point up this "prejudice" factor. In Baird v. Koerner, 46 an attorney mailed a check to the Internal Revenue Service as payment for delinquent taxes without revealing the identity of the delinquent taxpayer. (He suggested that the money be deposited in the account for unidentified collections.)

${ }^{43}$ Kaufman v. United States, 212 Fed. 613, 618 (2d Cir. 1914).

${ }^{44}$ See, e.g., In re Kaplan, 8 N.Y.2d 214, 168 N.E.2d 660, 203 N.Y.S.2d 836 (1960); Elliott v. United States, 32 Wash. L. Rep. 293 (1904), where the court applied the privilege to protect a testator's identity, since "it is essentially a confidential and privileged communication .... and few attorneys would be employed to draft wills if it were understood that they were at liberty to disclose the fact to any person, or upon any occasion, when disclosure might be desired." Id. at 297.

45 See. e.g., Chirac v. Reinicker, 24 U.S. (11 Wheat.) 280 (1826). Chirac upheld the attorney-client privilege where disclosing the identity would reveal not only the fact of employment but the reason for the employment. See Annot. 1916 L.R.A. 602; 58 AM. JUR. Witnesses $§ 507$ (1948).

46279 F.2d 623 (9th Cir. 1960), 13 ALA. L. Rev. 196 (1960), 47 VA. L. Rev. 126 (1961). The bizarre factual situation presented by Baird $v$. Koerner is complicated by the fact that Baird actually claimed the privilege on behalf of a communication made to him by the attorneys and accountants of the unidentified taxpayers. Allegedly the actual names of the taxpayers were never revealed to him, but the court disregarded his lack of knowledge of the ultimate client's identity and decided the case as if Baird were claiming the privilege on behalf of the taxpayers. The court treats the accountants and attorneys as agents of the taxpayers and, as such, any communications by them to Mr. Baird, which were set in motion by the taxpayers, came within the privilege. City \& County of S.F. v. Superior Court, 37 Cal.2d 227, 236-37, 231 P.2d 26, 31 (1951); See 8 Wigmore, Evidence $\$ 2317$ (3d ed. 1940). 
The money payment was presumably motivated by a desire to place the undisclosed taxpayers in a better position in the event criminal charges were brought against them by the Internal Revenue Service. Under these circumstances the court held that the name of the client was privileged, since the name was material only as an acknowledgement of the client's guilt. Baird represents surprising subordination of the interests of the Internal Revenue Service. 47 The taxpayers would have been subject to possible imposition of a criminal penalty for willful evasion of income tax or willful failure to pay a tax.48 By its implied approval of the gambit employed, the court may well have hampered severely the Internal Revenue Service in its efforts to deter potential tax evaders. The policy of promoting freedom of consultation may have been upheld by applying the privilege; but it is doubtful that this policy was strong enough to outweigh the substantial interests of the Internal Revenue Service which should have been placed on the other side of the scale.

In another recent case, Ex parte Enzor, ${ }^{49}$ the Alabama Supreme Court prevented a grand jury from requiring an attorney to reveal his client's identity under incriminating circumstances. In Enzor the attorney was asked "to give ... the name of the election official ... in the last Democratic Primary who told you that he had been offered a sum of money $(\$ 100.00)$ to miscount or tamper with the election returns." 50 The court stated that "if the client had already accepted the bribe, he had violated the law and the authorities seem to be uniform that, in such a case, the identity of the client would be privileged."51 The promotion of freedom of consultation and the social undesirability of obtaining from an attorney incriminating evidence against his client were substantial enough to outweigh the interests of the grand jury in investigating election frauds. The communication, if in fact the client had accepted the bribe, clearly came within the policy and the technical rules of the attorney-client privilege; and for the court to avoid applying the privilege would have been a denial of the very existence of the privilege.

47 The present tendency of the courts has been to subordinate the policies behind various exclusionary rules of evidence to the interests of the Internal Revenue Service. See In re Albert Lindley Lee Memorial Hospital, 209 F.2d 122 (2d Cir. 1953); Falsone v. United States, 205 F.2d 734 (5th Cir. 1953), cert. denied, 346 U.S. 864 (1953). In a recent case an attorney appeared before an agent of the Internal Revenue Service pursuant to a summons directing him to bring the records of a certain company. Other than to state his name and occupation he refused to answer all questions on the basis of the attorney-client privilege. The court in flatly disapproving of this practice stated that: "There is no such all-embracing principle, or talismanic formula, as sought to be advanced by respondent [the attorney]. ... The fact of representation is not within the privilege." Gretsky v. Miller, 160 F. Supp. 914, 915 (D.Mass. 1960).

48 INT. REv. CODE OF 1954, \$\$7201-02.

4970 Ala. 254, 117 So. 2d 361 (1960).

so Id. at 256,117 So. $2 \mathrm{~d}$ at 362 .

s1 Id. at 260,117 So. $2 \mathrm{~d}$ at 365 . 
Both the Enzor and Baird cases were based on Ex parte McDonough52 where a grand jury sought disclosure of the identity of a certain client who had retained an attorney to defend the parties under investigation. In $M c$ Donough the court sustained the privilege in order to protect the client's identity because, under the circumstances of the case, its revelation was material "only for the purpose of showing an acknowledgement of guilt on the part of such client of the very offenses on account of which the attorney had been employed to defend him." 53

The third of the recent cases which appears to be controlled by a "substantial prejudice" factor is In re Kaplan. ${ }^{4}$ In Kaplan the attorney had been employed to pass certain information to a waterfront investigating committee without revealing the client's identity because of fear of outside reprisals. The court in Kaplan wisely sustained the privilege as to the client's identity and stated that: "Usually, it is not the client's name but the client's communication to his lawyer which is held to be sacred, and so, ordinarily, there is no need to conceal the name to preserve the confidence. But here the client's communication had already been divulged ... and it was the client's name that deserved and needed protection for fear of reprisals...."55 Not only did the court promote freedom"of consultation by privileging the client's identity, but, in addition, its decision promoted the interests of the investigating committee which was seeking information about illegal waterfront activities. Information may be more readily available to the committee, since potential informants will have less reason to fear reprisals. In re Kaplan was supported by two previous New York cases which sustained the privilege where the client's identity would show his connection to an allegedly illegal sale of property, 56 and where the client's identity would show his allegedly negligent participation in an automobile accident. 57

In all three of these recent cases it seems clear that the client's identity under the circumstances, was in fact a confidential communication. The cases

52170 Cal. 230, 149 Pac. 566 (1915), noted favorably in 29 HARv. L. Rev. 109 (1915) 3 CALIF. L. REv. 497 (1915). Compare 3 VA. L. Rev. 82 (1915). English cases, although following the same majority rule as the United States, Bursill v. Tanner, 16 Q.B.D. 1 (1885); Levy v. Pope, $M$ \& $M 410,31$ Rev. R. 743 (1829), recognize an exception similar to $M c D o n o u g h$ where the client would be prejudiced by the attorney's revealing of his name. Jones v. Pugh, 12 Sim. 470, 41 Eng. Rep. 567 (Ch. 1842); Foote v. Hayne, 1 C. \& P. 545, 28 Rev. R. 788 (1824).

53170 Cal. at 237, 149 Pac. at 568.

548 N.Y.2d 214, 168 N.E.2d 660, 203 N.Y.S.2d 836 (1960).

558 N.Y.2d at 218,168 N.E.2d at 661,203 N.Y.S.2d at 839.

56 In re Shawmut Mining Co., 94 App. Div. 156, 87 N.Y.Supp. 1059 (1904). Compare Carnes v. Platt, 136 N.Y. Super. Ct. 361 (1873); Williams v. Fitch, 18 N.Y. 546 (1859).

57 Neugass v. Terminal Cab Corp., 139 Misc. 699, 249 N.Y.Supp 631 (Sup. Ct. 1931). The court distinguishes the majority cases on the basis that the client in the case before it was not seeking the use of the courts, but rather that someone was seeking to bring an action against him. 
collectively represent a shift in judicial attitude towards protecting the client's identity when under the same circumstances other communications to an attorney would be protected.

In order to decide in the particular case whether or not the claim of privilege should be allowed, the policies underlying the two lines of cases must be considered. Primarily, the problem is one of balancing interests. 58 The classical balance that has resulted in the attorney-client privilege has been the weighing of the policy of promoting freedom of consultation against the policy of full disclosure of the truth. The balance, however, is not immutably weighted, and at the periphery of the privilege specific interests are normally placed on the scale. For example, in Baird v. Koerner 59 the legitimate interests of the Internal Revenue Service in seeking to punish a tax evader60 were subordinated to the interest of the individual litigant in avoiding prejudice. Certainly in situations such as In re Kaplan, where both the interest of the client and the interests of the investigating committee can be promoted, the scale becomes overweighted in favor of applying the privilege.

The cases where the majority rule has been upheld supposedly have struck the balance in favor of the "overriding" judicial policy of full disclosure of the truth.61 They have subordinated "the slight, though real objection of one actual client [to] ... that body of prospective clients, the public."62 More realistically the courts which have denied the privilege appear to be impressed with a certain degree of sharp practice which seems to underlie many of the attempts to suppress the proof of professional employment. ${ }^{63}$ Nevertheless, under certain circumstances, such as those presented in the Kaplan and Enzor cases, apprehension about sharp practice should not prevent the courts from

58 For a detailed analysis of this approach see Mauch v. Commissioner, 113 F.2d 555, 556 (3d Cir. 1940).

59279 F.2d 623 (9th Cir. 1960).

60 The factual situation of Baird was probably affected by the Internal Revenue Service's shifting of emphasis from tax collection to deterrence. Consequently, in the past ten years criminal indictments have been filed in a much greater percentage of cases. The problem posed to attorneys is that in many instances the taxpayer's attorney has become, through cooperation with the Internal Revenue Service, an active contributor to the taxpayer's prosecution. For a partial discussion of this problem see Sokol, Cause for Alarm, CHI. BAR REC. 63, (1956); Lipton, Privileged Communications, N.Y.U. 13TH ANNUAL INSTITUTE ON FEDERAL TAXATION 955 (1955).

61 Where newspaper reporters have sought to conceal the identity of their sources, the policy of full disclosure has also generally prevailed. E.g., People ex rel Mooney v. Sheriff, 269 N.Y. 291, 199 N.E. 415 (1936). In many instances the reporter will go to jail rather than reveal the identity of his source, so that the unknown source will continue to give him information. As a result, many states have by statute privileged the right of a newspaper reporter to withhold his source of information. For a collection of the statutes, see 8 WIGMORE, EVIDENCE § 2286 n.13 (3d ed. 1940, Supp. 1951 and 1957).

62 Mauch v. Commissioner, 113 F.2d 555, 556 (1940).

63 See MCCORMICK, HANDBOOK OF THE LAW OF EvidenCE $\$ 94$ (1954). 
protecting an individual client's identity. In these situations, in which a substantial prejudice factor is involved, the courts should promote freedom of consultation by protecting the client's identity in the same manner as they protect any other confidential communication to an attorney.

\section{MEDICAL DEDUCTION: TEST AND APPLICATION}

The Internal Revenue Code of 1954 provides relief for taxpayers who have incurred substantial medical costs during the tax year. ${ }^{1}$ Section 2132 allows a limited ${ }^{3}$ deduction of "the expenses ... for medical care of the taxpayer, his spouse, or a dependent...."4 Although the original purpose of the allowance was not clearly explained, 5 the medical deduction is now generally recognized as an additional element of "ability to pay" considerations in the federal income tax system. 6

The expenses of medical care, as defined by the Code, are the amounts paid "for the diagnosis, cure, mitigation, treatment, or prevention of disease, or for the purpose of affecting any structure or function of the body (including amounts paid for accident or health insurance), or ... for transportation primarily for and essential to... [the enumerated functions]."7 The courts have encountered several recurring problems in applying this definition of medical expense. It was not made clear, for example, whether expense

1 By providing tax reductions to those who have incurred medical costs, Congress inflicts a greater burden upon other taxpayers. Thus, to a degree, the costs of illness are diffused throughout the society. For analyses of the economic effects of this form of "socializing" medical care, see Kahn, Personal Deductions in the Federal Income Tax 126-61 (1960); Jensen, Medical Expenditures and Medical Deduction Plans, LX J. PoL. Econ. 503-24 (1952).

2 A medical deduction was originally provided in 1942 as an amendment to the 1939 Code. Revenue Act of $1942, \S 127,56$ Stat. 825 . The definition of allowable deductions was substantially maintained in the 1954 Code.

${ }^{3}$ Section 213 (a) stipulates that only medical costs in excess of $3 \%$ of adjusted gross income are deductible. Sections $213(\mathrm{c})$ and $213(\mathrm{~g})$ establish maximum amounts per person.

4 INT. REv. CODE OF 1954, $\$ 213$ (a). A deduction is not the sole means of providing tax relief for medical expenses. For a discussion of alternative proposals, see Jensen, Rationale of the Medical Expense Deduction, 7 NAT'L TAX J. 274 (1954).

5 There is, for example, evidence that the deduction was to be a temporary, wartime relief measure. S. REP. No. 1631, 77th Cong., 2d Sess. 6 (1942): "This allowance is recommended in consideration of the heavy tax burden that must be borne by individuals during the existing emergency and of the desirability of maintaining the present high level of public health and morale."

${ }^{6}$ See Note, Medical Deduction: Scope and Purpose, 28 IND. L. J. 264 (1953). Judge Frank viewed the provision as an unparalleled display of legislative charity. Dissenting in Ochs v. Commissioner, 195 F.2d 692, 695 (2d Cir. 1952), he observed that, in allowing a deduction for medical costs, "for once, Congress, although seeking revenue, shows it has a heart...."

7 INT. REv. CODE OF 1954, § 213(e). 